\title{
COCKROACHES: FROM BELIEF NARRATIVES TO THE CONTEMPORARY VISUAL PRACTICE OF CATHERINE CHALMERS, OR HOW COCKROACHES HAVE SURVIVED ON EARTH FOR MORE THAN 320 MILLION YEARS
}

\author{
Suzana Marjanić \\ Institute of Ethnology and Folklore Research \\ Zagreb, Croatia \\ Email: suzana@ief.hr
}

\begin{abstract}
This article, ${ }^{1}$ developed on the meeting point of ethnozoology and critical animal studies, is an overview of the role of cockroaches (of which there are around 3500 species) in customs and beliefs of certain ethno-traditions, with a special emphasis on Russian and Croatian, i.e. South Slavic, ethno-traditions in terms of context. In the first part of the paper, I have chosen to present the two aforementioned Slavic examples, considering that they are contradictory in the ethics of their relationship towards cockroaches: while cockroaches, particularly the black ones, were respected in Russian ethno-tradition, almost as pets that bring happiness and prosperity to a household (we could call them pet amulets of sorts) (cf. Gura 2005), they were treated merely as pests in Croatian ethnotradition, as is the case today.

In the second part of the paper, I supplement the aforementioned folklorist and ethnologic perspective (zoofolkloristics and ethnozoology) with animal studies. This includes the question of animal rights from a contemporary perspective, whereby I concentrate on aggressive insecticides and exterminators of cockroaches today, as well as on the research of the advertising strategies that contain militant killing performatives (e.g. Raid commercials). I conclude with the discussion on the ethic and aesthetic in the visual art of Catherine Chalmers, who kills cockroaches in the name of art, for the purposes of some of her works, albeit simultaneously demonstrating that even the "lowly" cockroach can be a subject of so-called high art.
\end{abstract}

Keywords: cockroaches, commercials, (critical) animal studies, folkloristic research, speciesism, visual arts 
Is there really nothing nice to be said about cockroaches? ... In the world of insects, their parental love for their offspring is one of the greatest, it is unsurpassable. ExhibitionŽohari-svijet kojiostaje (Cockroaches-A World That Remains), Croatian Natural History Museum, Zagreb, 2018

This article on cockroaches, insects of the order Blattodea and loved by few, which have lived on Earth for more than 300 million years (cf. Grush 2016) and will survive the climate change apocalypse (which is becoming increasingly probable), was written within the scope of two fields of research - one based on folklore and the other on animal rights (animal studies and particularly critical animal studies). Specifically, the first segment of the paper, based on the research performed by Aleksandar Gura (2005), lists examples from Russian ethno-tradition, comparing them with respective examples from Croatian ethno-tradition. I have limited my comparisons to these two Slavic examples for two reasons: the first is that Aleksandar Gura is the author of the first systematic research of the symbolism of animals in Slavic folk tradition (as the title of his book suggests) and hence, regarding Slavic ethno-traditions, I have opted for the Russian (which is Gura's field of research as a folklorist) and the Croatian one (as my own field of folkloristic research). The second reason is that the aforementioned ethno-traditions possess divergent relationship ethics towards cockroaches. While cockroaches, primarily the black ones, were valued in Russian ethno-tradition and treated almost as pets that bring good fortune and prosperity to a household (we could call them pet-amulets of sorts), in Croatian ethno-tradition they were regarded only as pests, that is, the same way they are perceived today.

In the second segment of the article, I supplement the aforementioned folkloristic and ethnological perspective (zoofolkloristic and ethnozoological) with research implemented in the field of animal studies and critical animal studies, which (especially critical animal rights) also includes issues of animal rights and contemporary perspectives. Briefly put, in order to obtain a perspective of the past and present relationship of humans with cockroaches, I supplement the folkloristic and ethnologic perspective (zoofolkloristics and ethnozoology) with animal studies, which also includes the question of animal rights from a contemporary perspective. Here, I place a special emphasis on Branislava Vičar's (forthcoming) critical animal research of advertising strategies for aggressive insecticides and exterminators that contain militant performative acts of killing (e.g. the Raid commercial). ${ }^{2}$ 
I conclude the aforementioned animal studies and critical animal studies perspective with another example of visual animal studies, i.e., a segment of animal studies, which addresses the question of ethics and aesthetics - the work of the artist Catherine Chalmers who, for the purposes of some of her works, kills cockroaches in the name of art, albeit simultaneously demonstrating that even the "lowly" cockroach can be a subject of so-called high art.

Therefore, I have written this paper as an intersection of folklore studies (zoofolkloristic and ethnozoological) on the one hand, and animal studies and critical animal studies on the other hand, in order to comprehensively document the relationship between humans and animals (cockroaches), from folklore beliefs to the contemporary relationship in which they are treated (only) as pests. According to numerous animal studies theoreticians, such cross-disciplinary research needs to include the totality of relationships between humans and animals, and therefore needs to go far beyond the limits of the zoofolkloristic and ethnozoological perspective (cf. Visković 1996: 11) in order to document the human-animal relationship, both of today and of the past. More specifically, animal studies is an interdisciplinary subject field in which animals are studied in a variety of cross-disciplinary manners; it is a study of the interactions and relationships between human and nonhuman animals. In other words, to cite Margo DeMello, programme director for Human Animal Studies at the Animals and Society Institute:

Human-animal studies (HAS) - sometimes known as anthrozoology or animal studies - is an interdisciplinary field that explores the spaces that animals occupy in human social and cultural worlds and the interactions humans have with them. Central to this field is an exploration of the ways in which animal lives intersect with human societies. (DeMello 2012: 4)

However, theoreticians in critical animal studies are of the opinion that the mainstream of animal studies has no connection at all with animal rights. Or, as a philosopher and seasoned activist Steven Best goes on to say: "Animal studies is everything to everyone - including welfarists, carnivores, speciesists, pro-vivisectionists, and sundry human supremacists and animal exploiters" (Best 2009: 13). Hence, Steven Best demands that mainstream animal studies be replaced by critical animal studies, an academic field of study dedicated to the abolition of animal exploitation, oppression, and domination (Best 2009: 13; cf. Marjanić 2017a: 128). ${ }^{3}$ 


\section{COCKROACHES WITHIN THE FOLKLORISTIC RESEARCH: TWO EXAMPLES FROM BYGONE DAYS - RUSSIAN AND CROATIAN}

The first research I seek to present - the folkloristic one - stems from the study of Russian philologist Aleksandar Gura, whose book Simbolika životinja $u$ slovenskoj narodnoj tradiciji (Symbolism of Animals in Slavic Folk Tradition, 2005) contains chapters in which he thematically observes domestic insects so-called parasites (fleas, lice, mites, cockroaches). As regards cockroaches, Gura focuses on their symbolism in Russian ethno-tradition, wherein they are considered harbingers of wealth and material wellbeing. Such folk beliefs usually apply only to black and not brown cockroaches. According to this belief, black cockroaches are not to be exterminated because they are thought to bring wealth. Furthermore, the reproduction or the emergence of prusaks - big black cockroaches - was considered especially good fortune in the home: "Many black cockroaches living in someone's home is a sure sign that fortune is coming that person's way" (cf. Gura 2005: 314-315). Gura points out that the function of the protector of the home in Russian ethno-tradition, characteristic of cockroaches and many other chthonic animals - reptiles and some insects (snakes, weasels, frogs, turtles, moles, worms, spiders, crickets, ants, etc.) - can be recognised from these beliefs, as is the case in Croatian ethno-tradition, wherein the role of the protector of the home is assigned to the snake. The most common reason for a ban on exterminating black cockroaches is that it may have an adverse effect on livestock (cf. Gura 2005: 314-315). When moving into a new house, they too were moved and fed, especially for big holidays, believing that the greater the number of black cockroaches, the better one's livestock would breed. In Vologda province, there was a belief that in every home there is a cockroach queena cockroach as big as a lamb. If sorcery is used to get her out of the house, all the landlord's livestock will die. And should the cockroaches leave the house on their own, this would be a sign of misfortune, most often signifying fire or death in the household (ibid.: 315-316).

Outside the borders of Russia, the ban on exterminating cockroaches, as well as mites and fleas, is completely different in nature and is usually related to the danger of these or other insects taking revenge on humans (the same reasoning applies to the ban on killing lizards, snakes, and some other reptiles and insects). The Hutsuls (Ukraine) believe that cockroaches must not be killed because their brothers (cockroaches) will take revenge on the person who insulted them (the Hutsuls), and fall into their meal (cf. Gura 2005: 315). ${ }^{4}$

With regard to Croatian folkloric material, ethnographer Milan Lang (18631953), in his monograph Samobor: Narodni život i običaji (Samobor - Folk Life and Customs) on the town of Samobor near Zagreb, ${ }^{5}$ wrote that the residents of Samobor are not very good at naming bugs, and cites the following types of 
cockroaches: švaba (Blatta tedesc $(h) a)^{6}$ and žohar (Blatta orientalis) (Lang 1992 [1915]: 50-51) (see Fig. 1). This very short record shows that Lang distinguishes the švaba and the cockroach, names which in Croatian and Serbian languages actually denote the same insect (Serbian bubašvaba, Croatian žohar). Furthermore, in the chapter titled "Nature" of the same monograph, Milan Lang writes about animals and insects separately. He introduces a separate subchapter with a speciesist relationship (speciesism - discrimination based on species membership) with insects, titled "Extermination of Animals and Vermin", detailing the ways cockroaches are killed (exterminated). He instructs the reader to pour some old beer into a high bowl and then place sticks or kindling around the edge of the bowl. The cockroaches will smell the beer, enter the bowl, get drunk and will not be able to climb back out. "Some put this mixture inside holes: one-third white flour, one-third powdered sugar, and one-third sodium borate, all well mixed. Of this - they say - all the cockroaches will die" (Lang 1992 [1915]: 178). Thus, when mentioning cockroaches, Lang is referring to the Oriental or black cockroach, which is usually said to leave an unpleasant odour on the surfaces on which he or she (I will not use "it", to avoid speciesist language!) moves. Furthermore, in contrast to these two traditional ways of cockroach destruction or extermination, today it is generally recommended to spray surfaces with insecticides based on deltamethrin, pyrethrin or fipronil, apply an insecticide gel or place traps with an attractant (cf. Blatta orientalis). However, there are eco-friendly alternatives to these dangerous and aggressive insecticides; these practices recommend using peppermint essential oil and vinegar for the removal of spiders and cockroaches, as they cannot stand the smell (Kos 2016).

SAMOBOR: ĽIVOTINJH.

bilica (Locusta viridissima), klop (Ixodes ricinus), Komarec (Culex pipicus), kojnska muha (Hippobosca equina), kosëc (Lebellula depressa) ${ }^{1}$, kršel, krvava vuš (Schizoreura lanigera), kućna baba (Pentatoma grisca), metũl (uopće svaki), molci (Tinea), mrâvec (Formica), muha (Musca domestica), obad (Tabanus bovinus), osä (Vespa vulgaris), pâvuk (Tenegaria domestica) ${ }^{2}$, rogač (Lucanus cervus), rogủ (sićušni kukčić, živi a brašnu i mekinjama, a poslije zalazi i u žito), stenica (Aconthia lectularia), strižavka (Fornicula auricularia), stršen (Vespa crabro), svilec (Bombyx mori; od njega neki goje gusjenice, koje zovu $\left.{ }_{n k a k c i}{ }^{\prime}\right)$, škorpijon (Scorpio europaeus), sostar (Cimex ornatus), spanišmuha (Litta vesicatoria). švaba (Blatta tedescha), tekuti (Mallo. phaga), vinske mušice (držo so oko vina i vinskoga tropa), vrlëc (Gryllotalpa vulgaris), vuš (Pediculus capitis; od njih su gnide), žižek (Calandra granaria) ${ }^{3}$, žohar (Blatta orientalis), žuti metul (Rhodoceras rhamni).

Figure 1. Excerpt from the monograph Samobor: Narodni život i običaji (1992 [1915]), written by ethnographer Milan Lang (1863-1953). 
In contrast to folkloric field records, which distinguish between the švaba and žohar types of cockroaches, some twenty years before Lang's monograph, in his zoological book Kukci (Bugs) (1887), biologist Mišo Kišpatić writes about the cockroach or švaba (Blatta, Periplaneta orientalis, Küchenschabe, Schwabe), offering a speciesist, "scientific" description: "A very disgusting and annoying occupant of our homes" (Kišpatić 1887: 188). He also mentions how to get rid of them, in a similar fashion to Lang, but points out that everything can be resolved in a natural way - it is only necessary to acquire a hedgehog: "The hedgehog is very eager to eat cockroaches so they can help us get rid of the cockroaches in the home" (ibid.: 190). However, unlike Lang, he mentions the difference between the cockroach and the rus (lit. "the Russian" (Blatta germanica, Deutsche Schabe, Russe, Blatta tedesc(h)a), which he states is the closest relative to the švaba (cockroach). He mentions that they are called the prus (Prussian) in Russia, as there it is believed that soldiers brought them to Russia from Germany after the Seven Years' War, since they did not exist in Saint Petersburg before that. He continues:

In Austria, it is thought that workers from the Russian border carried them into Czech glass plants, from where they expanded into Austria. One way or the other, only the rus (Russian) is now widespread throughout the world. (Kišpatić 1887: 190)

Furthermore, he states in the description that the rus is smaller than the cockroach, has a brownish-yellow colour and is exterminated in the same way as the cockroach. In addition, he also mentions a more "humane" way of destroying the rus:

The rus is very sensitive to sudden temperature changes; it is advised to open doors and windows wide during the winter, for it is the way that Czech farmers clean their houses from the rus. (Kišpatić 1887: 191)

In this part of the article, I concentrate on two Slavic (Russian and Croatian) examples, since they are contradictory in their ethics of relationship with cockroaches; while cockroaches, primarily the black ones, were admired in Russian ethno-tradition, considered almost pets that bring happiness and prosperity to the household (we could consider them as pet amulets of sorts) (cf. Gura 2005), they were treated in Croatian ethno-tradition merely as pests, as is also the case today. It is exactly my own enthusiasm about this animal-friendly relationship with cockroaches in Russian ethno-tradition that served as one of the incentives for writing this article, as it is evident that the aforementioned relationship also testifies to the yearning of humans to unify with nature, which is even older than the human tradition of animal rights and the foundations of environmentalism (Sax 2007: 46). 


\section{CONTEMPORARY ANIMAL RIGHTS RESEARCH: COCKROACHES FROM PESTS TO PETS}

As I have stressed in the introduction, in the second part of the article I supplement the aforementioned folkloristic and ethnological perspective (zoofolkloristics and ethnozoology) with contemporary animal studies and critical animal studies perspective. Here, I address the aggressive use of insecticides and exterminators of cockroaches of today, as well as the advertising strategies that contain militant performatives of killing (e.g. the Raid commercial), by referring to Slovenian critical animal theoretician Branislava Vičar (forthcoming) who discusses the speciesist representation of cockroaches and other insects in commercials. She provides an example of an advertisement for the Raid insect repellent used to kill insects that are commonly considered parasites and pests in speciesist culture. Speciesist verbs used for cockroaches - get rid of, exterminate, kill, destroy - can also be found in the folkloristic scope, as we have also seen, for example, in Lang's notes on the safest ways to get rid of cockroaches. The author also observes that, in their earliest days, insecticide ads were twice as long as modern advertisements. As an example, Vičar says that the original ad for Raid was one minute long, while a current Raid Television Commercial is only 29 seconds long. She also points out that modern advertisements consist of several structural units because they are characterised by short, rapidly changing shots. She interprets such a commercial according to the animal rights research: the first scene depicts various species of insects in fear of Raid. The author transcribes all five shots from the first scene and I describe three of them here:

First shot. Long shot of a net on a window. Gradual close-up of a fly that enters through a hole in the net. The fly yells.

Fly: "RAAAIIID is here!!!"

Scene 2. Close-up of an overflowing sugar bowl, followed by a medium shot of ants jumping out of the sugar, shouting and placing their drawn-on "human" hands on their heads. The background is empty. The horizontal lines indicate that it is a wall.

Ant: "RAAAIIID!!!"

Fifth shot. Close-up of a bug, yelling and running away in fear.

Cockroach: "RAAAIIID!!!"

...

A huge cloud of insecticide appears, taking up the entire space, with the following writing on it: "ALL TYPES OF INSECTS FROM THE INSIDE". [Sound of spray.] 
Narrator's voice: Yes, Raid beats flies, mosquitoes, cockroaches, ants - all types of insects from the inside. (Vičar forthcoming) ${ }^{7}$

It is equally noticeable that older advertisements use the speciesist verb to kill, while more recent advertisements tone down the speciesist, "terminatorlike" attitude towards cockroaches by using a lighter version - the verb to beat. Nevertheless, it demonstrates our speciesist attitude towards insects equally well or, as theoretician of animal rights Joan Dunayer states, it demonstrates a discriminatory practice, "a failure, in attitude or practice, to accord any nonhuman being equal consideration and respect" (Dunayer 2004: 1-5).

Looking at the ways in which insecticides are used against cockroaches (and other insects that modern civilisation regards as pests), we can conclude that in the past, at least some cultures - as demonstrated by the Russian ethno-tradition - were far more considerate towards cockroaches. On the other hand, cockroaches in Croatian folk tradition were considered to be pests in the same way they are today, but they were still not killed with as violent methods as they are today, when only aggressive insecticides are applied. In Czech folk tradition, for example, it was advised to open the windows to get rid of cockroaches during winter months (Kišpatić 1887: 190). In Croatian folk tradition one could use a hedgehog or a cat to remove the cockroaches from the food chain. Using a hedgehog to get rid of cockroaches implies considering the latter in the context of the circle of life: hedgehog (predator) - cockroach (victim), whereas the cockroach will perform the role of the predator in relation to some other living beings, which is, in fact, in line with the discursive nature of the circle of life. However, it can be noticed that some exterminators do not use militant means for destroying cockroaches. For instance, Chicago exterminator Hugo Hartnack, "author of a leading pest-control guide, recommended simple homemade and commercial cockroach traps that required no poison. Popular trap designs involved ramps leading into a jar or coffee can baited with such favorite roach foods as stale beer. More important, Hartnack advised caulking cracks and crevices to eliminate household harborages, and sanitation to deprive roaches of food. The parts of his guidebook dedicated to roaches suggest chemical remedies only as 'very successful emergency measures,' in contrast with his strenuous promotion of hydrocyanic acid gas (HCN) for bedbugs" (Biehler 2013: 88).

Furthermore, the starting point for contemporary cockroach extermination is mostly the hygienic niche, or what anthropologist Mary Douglas (1984 [1966]) in her structuralist interpretations terms the purity-danger dichotomy; however, it is interesting to note that there is no mention of cockroaches in this dichotomy. That is, black cockroaches are known to roam around the sewage system and transport microbes to surfaces for food or to food on their feet. They 
are known to carry more than thirty sorts of bacteria and numerous causes of disease (cf. Crni žohar).

The aforementioned militant cockroach extermination demonstrates that, as far as Western culture is concerned, cockroaches are today mostly detested. ${ }^{8}$ This derogative attitude is clearly a result of urbanization of the post-industrial revolution and a detachment from the context of agriculture - the introduction of new cultural norms of hygiene/purity by which, to use Mary Douglas' purity-danger dichotomy, anything that is connected to creeping is placed in the context of a possible danger to the human species. In European history, the changes in hygienic habits and grooming were not prompted by a desire for cleanliness but by their attractiveness and trendiness. The nineteenth century is cited as the century of great changes in the matters of hygiene. At the time, very few people had a bathroom in today's sense of the word; the toilet was usually located separately, while up until the mid-twentieth century bathing was performed in a heated room (the kitchen or, more commonly, the bedroom, using a trough and a wash basin), often in the presence of other people (the servant or relatives) (cf. Sladetić 2016: 131; Leismann \& Padberg 2010: 25).

Boria Sax stated that "[o] ur understanding of animals is so intimately bound up with our own self-concepts as human beings, we can hardly hope to separate the two completely. Representations of animals have always contained projections of our deepest hopes, fears and aspirations" (Sax 1990: 146). Within human civilisation, cockroaches have therefore found themselves on the receiving end of our hatred.

The cockroaches' positive aspects - presented, for example, at the 2018 exhibition under the heading Žohari - svijet koji ostaje (Cockroaches - A World That Remains), the first exhibition on cockroaches in Croatia held at the Croatian Natural History Museum (see Fig. 2) - are rarely introduced. The exhibition opened with a zoo-ethical question: Is it really true that we cannot find anything nice to say about cockroaches, even though not a single attack of a cockroach on a human has ever been recorded? In fact, out of over 4,000 species that enter our households, only 1 percent of cockroach species cause fear and loathing in humans. The exhibition documented actual contemporary tendencies to turn cockroaches from pests into pets, as is particularly illustrated by the giant Madagascar hissing cockroaches (Gromphardorhina portentosa) which, as proven by their name, produce peculiar hissing sounds, due to which they are interesting to children. Due to their ability to hiss, their size and lack of odour, they began to be kept as pets. This testifies to the rise of the culture of petishism (culture of pet-keeping), even of the insects, as in the case of Madagascar cockroaches, which do not live in houses, flats and other housing units, but rather in the forests, usually hiding underneath fallen leaves, rotten branches and logs. ${ }^{9}$ 
The speciesist attitude towards cockroaches can also be seen in children's illustrated books, in which they are presented mostly as pests. ${ }^{10}$ It is true that cockroaches are usually described in illustrated books as one of the oldest and most successful living creatures on Earth; however, the rest of their description is given along the lines of speciesist definitions of so-called pests. In short, when educating children about insects, almost nothing has changed in the modern world. In 1897, the Croatian magazine Smilje offered an educational article for children on how to kill bugs considerately because they are considered pests:

In many countries, people are rewarded for exterminating them. Therefore, children, you too should crush the pestilent insects, but in doing so you must not torture them, but rather give them to a pig to eat or drown them in hot water. (Smilje 1897 as cited in Batinić 2013: 209)

While in the nineteenth century the children were taught to kill beetles, today, in this particular case, the children are taught how to use Raid against insects, that is, the so-called pests.

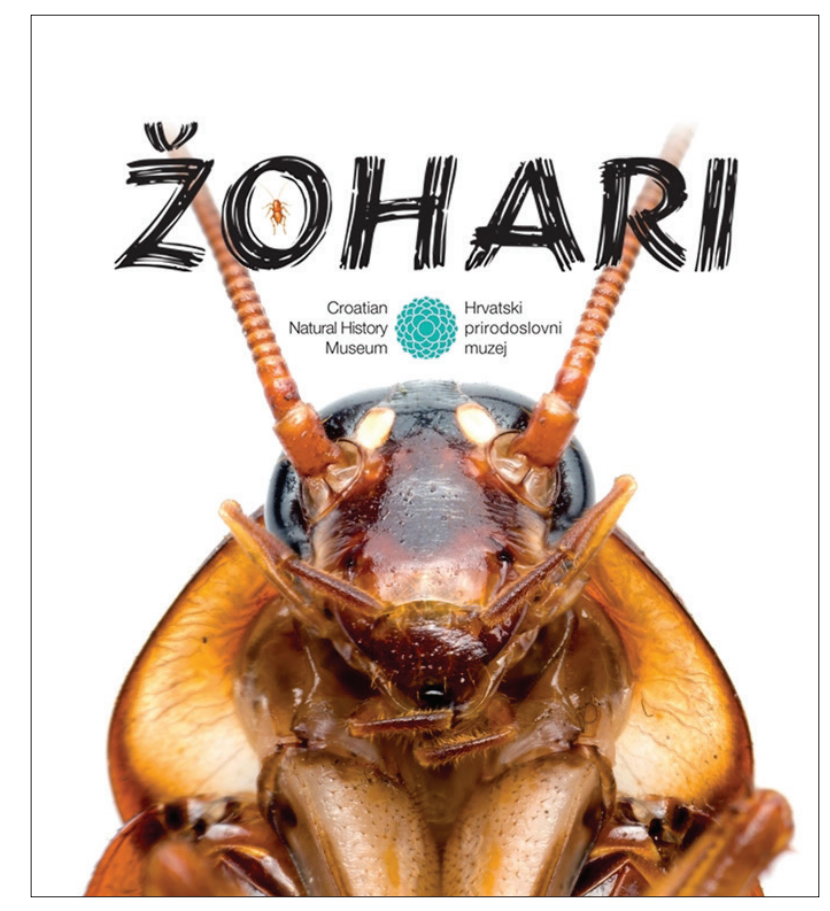

Figure 2. Poster for the exhibition Žohari - svijet koji ostaje (Cockroaches - A World That Remains), Croatian Natural History Museum, 2018. 
A recent case of our speciesist attitude towards cockroaches is demonstrated in the science education kit produced by Backyard Brains (Fig. 3), which lets children implant electrodes into a cockroach's brain and then control the beetle with a smartphone app. The organisation People for the Ethical Treatment of Animals (PETA) protested against these mind-controlled Robocop Roach insects, but Greg Gage, co-founder of Backyard Brains, responded to the accusations with a speciesist attitude: "These are cockroaches that people would easily kill in their apartments" (The RoboRoach Bundle; Bittel 2013).

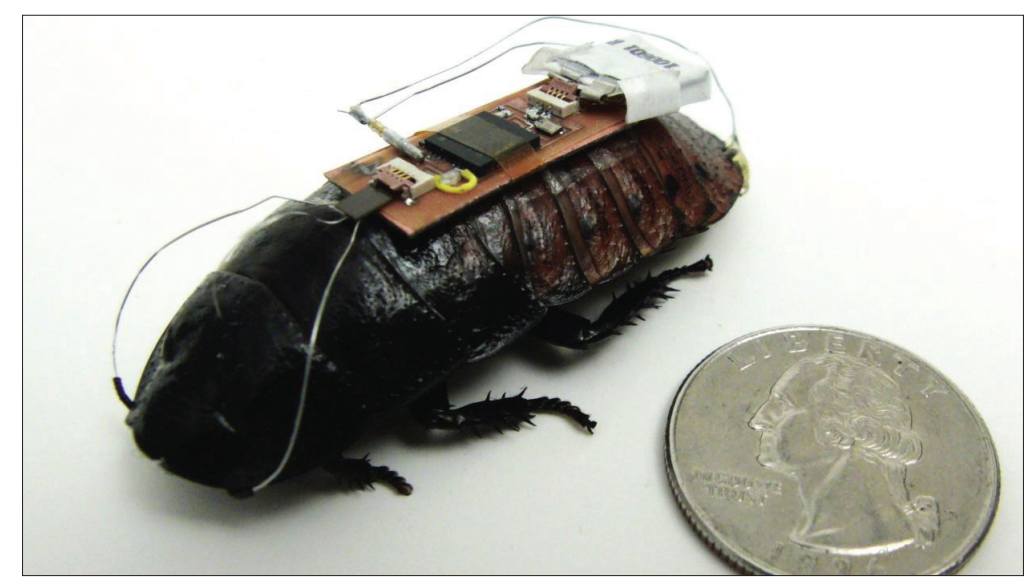

Figure 3. Robocop Roach: cyborg cockroach with a remote control "backpack" (Sandle 2013). ${ }^{11}$

\section{COCKROACHES IN VISUAL ART PRACTICE: FROM SYMBOLISATION TO EXPLOITATION}

I would like to conclude with another example from visual animal studies which is a segment of animal studies - presenting conflicting notions between ethics and aesthetics. I present the use of cockroaches in contemporary art practice by citing the example of Catherine Chalmers, a photographer who uses cockroaches in her photographs and videos. The artist kills cockroaches in the name of art for the purposes of some of her works (video work Execution, part of the American Cockroach video series), ${ }^{12}$ albeit simultaneously demonstrating that even the "lowly" cockroach can be the subject of so-called high art. In her works Crawl Space ${ }^{13}$ and American Cockroach ${ }^{14}$, she demonstrates how cockroaches find their natural habitat in domestic spaces - under the sink, in ventilation ducts, in door and window frames, between the walls of bathrooms, 
which provide them with shelter when searching for food. The American cockroach is very similar to its human hosts because, just like humans, he or she is an omnivore and lives with us in our habitats today just as we used to live in caves with so-called wild animals. In short, the artist demonstrates how the humble cockroach can be the subject of art. Catherine Chalmers' work also includes a critique of American racist history, since the American cockroach came to North America as an immigrant, on ships from Western Africa during the early days of the slave trade.

In her videos Crawl Space and American Cockroach (Fig. 4), Chalmers shows cockroaches in their domesticated environment, i.e., human habitats; however, in her video $S a$ fari $^{15}$ she releases cockroaches into the wild, where they encounter animals they would normally never encounter in their own habitat, i.e., human homes (cf. Baker 2013: 68). The artist's work also raises the question of artistic freedom since she also kills them for the sake of her art. Thus, we arrive at a parallel between Kafka's huge insect Gregor Samsa and Chalmers' cockroaches, in which the cockroach is transformed from symbolic matter into an object of exploitation (cf. Copeland 2003: 164), or in this case artistic exploitation since, as Chalmers demonstrates, he or she can be killed in the name of art. ${ }^{16}$ Firstly, let us note her symbolic interpretation of cockroaches:

Insects are a window into the unimaginable. Their biology and behaviours are routinely bizarre and enigmatic to us - they are refreshingly outside the human perspective. I think that our experience can be enhanced by an attempt to understand and give meaning to other life forms. Yet, is it possible that a human-centric viewpoint is setting the stage for an impoverished environment? (Chalmers 2004)

On the other hand, however, we also see her exploitative use of cockroaches; it is truly horrifying to watch the ways in which the artist is prepared to murder cockroaches for her photographs and videos.

While making this video, Ms. Chalmers said, she got very upset, not because of the Holocaust parallel, but because she thought she had actually put the roaches through an agonising death. Previously she had always knocked her roaches out by chilling them. But Betty Faber, an entomologist, told her to try carbon dioxide. So she put the roaches in the chamber and with a pipe pumped in the gas from dry ice, which is frozen carbon dioxide. The roaches went into 'dramatic convulsions', she said. 'They tossed themselves all over the place, threw themselves against the walls. Then they all fell on their backs. She thought: 'I can't show this. It's visually too disturbing.' But then, as the videotape kept rolling and the dry ice cleared, the cockroaches rose from the dead. Their legs started kicking. 'The most beautiful part is their getting up,' Ms. Chalmers said. 
She decided to show the uncut video from this point on. It shows the cockroaches as survivors. 'I wanted to show their character,' Ms. Chalmers says. 'They keep coming back.' (Boxer 2003)

In this sense, Chalmers' thoughts on cockroaches are contradictory - they are ethically dichotomous, ranging from symbolisation to exploitation.

In the book Artist / Animal (2013), his third work in the field that could be termed visual animal studies (visual artist - animal studies), Steve Baker introduces and zoo-ethically defends the artists who kill animals in the name of art. It can be assumed that Steve Baker, as an art historian, does not condemn such artwork and believes that he can learn something from it regarding the exploitative and symbolic relationship between humans and nonhumans. To quote Baker himself, in the context of his interpretation of Rat Piece (1976), a performance by Kim Jones in which the artist set on fire several rats, and Helena (2000), an installation by Marco Evaristti:

But simply to condemn such works is to learn nothing from them. It is to undermine the very notion of art, to prefer compliance to creativity, for fear that animal abusers might get away with mischievously 'excusing their misdeeds as instances of performance art'. (Baker 2013: 17)

In the aforementioned book, Baker thus includes three artists who killed animals, caused the animals' deaths during the project itself, or used previously killed animals. They are Catherine Chalmers, who killed cockroaches, Eduardo Kac and his genetically modified rabbit Alba (the project ended with her death in a French laboratory), and artist Catherine Bell who, in her performance Felt is the Past Tense of Feel (2006), ate raw squids (pre-bought), with which - or, more specifically, with whose black ink - she purged the trauma caused by losing her father to cancer.

As an art historian, Steve Baker does not separate ethics from aesthetics. He does not want to be "an idiot, a voyeur, or a moralist", to paraphrase the first page of the introduction to his book Artist / Animal (2013) which is, in turn, a paraphrase of Marco Evaristti's statement (Baker 2013: 1), wherein he sought to ethically and aesthetically defend his installation Helena, during which one goldfish had been killed (cf. Baker 2013: 1; Marjanić 2017b). Baker's most pertinent zoo-ethical questions are the following: 'Can a contemporary artist be trusted with animals, living, or dead? Can they be trusted to act responsibly, ethically, when their work engages with questions of animal life?' (Baker 2013: 1)

Specifically, while the previous example of visual animal studies, the Raid commercial, demonstrated our commonplace, everyday relationship towards cockroaches as pests, the artwork of Catherine Chalmers - which I list as an example of artistic visual animal studies - addresses the question of ethics and aesthetics towards the aforementioned insects since the artist treats them as 
aesthetic objects (when she kills them for some of her works) on the one hand, and as aesthetic symbols (when she uses them to critically consider America's racist past). It is exactly the dimension of treating them as aesthetic objects that the artist uses to also address the ethical question of using animals in the name of art or, in this case, killing them in the name of art, which is not an unfamiliar practice in postmodern art, as Steve Baker systematically documented in his books $(2000,2013)$.

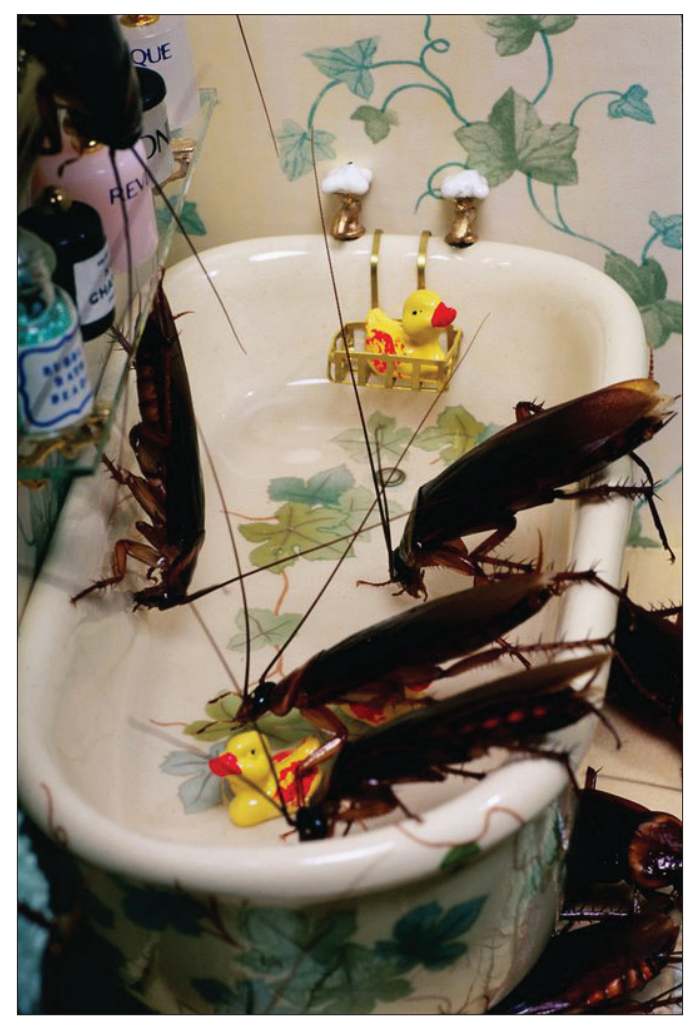

Figure 4. Catherine Chalmers: Drinking, C-print, 60" $x$ 40", from the series American Cockroach (2005). Source: https://www.catherinechalmers.com / residents-1, last accessed on 7 October 2019.

\section{TOWARDS... NOTHING}

Catherine Chalmers' killing of cockroaches in the name of art can be compared to the aforementioned cyborg-cockroaches and the justification given by the company that designed the idea. Such scientific or pragmatic reasoning, as well 
as artistic or aesthetic reasoning for using animals in the name of science/art is reminiscent of the zoo-metaphors incorporated in racism; briefly put, they testify of the parallelism between racism and speciesism, in a racist manner in which we used to treat slaves, and in a speciesist manner (speciesism - discrimination based on species membership) in which we treat animals even today. Hence, Charles Patterson (2002) noted that, during World War II, the Japanese were vilified as "animals, reptiles, or insects (monkeys, baboons, gorillas, dogs, mice and rats, vipers and rattlesnakes, cockroaches, vermin - or, more indirectly, "the Japanese herd' and the like)", as John Dower wrote (as cited in Patterson 2002: 39). This vilification campaign paved the way for a "war without mercy" in the Pacific, which culminated in the dropping of atomic bombs on Hiroshima and Nagasaki (ibid.). Stories of hate and racist animal metaphors go even further:

During the Gulf War in 1991, American pilots described killing retreating Iraqi soldiers as a 'turkey shoot' and called civilians who ran for cover 'cockroaches'. As always in wartime, animal images dehumanise the enemy and facilitate his destruction. (Patterson 2002: 43)

Prompted by these examples of killing animals in the name of art, and with respect to the often emphasised and ubiquitously pronounced aesthetic motto of the freedom of artistic creativity, the following question imposes itself: is it, after all, senseless to pursue ethical accountability of the artists of such works of art? Especially, as animal rights activist Alf Waibel reminds us with regard to animal victims still being exploited by Hermann Nitsch in his theatre company, the Orgies Mysteries Theatre (Das Orgien Mysterien Theater): ‘... the freedom of artistic expression is in our constitution, while the rights of animals and the laws protecting them from suffering and death, are not' (Waibel 1998).

And finally, is it, after all, not hypocritical to single out such artistic acts created on the basis of slaughtered animals, while simultaneously being surrounded by animal Holocaust on a daily basis? In order to avoid being criticised for equalising the Holocaust committed against the Jewish people and the Holocaust against animals, it should be stressed that the creators of this analogy - including, for example, Theodor W. Adorno (cf. Adorno et al. 1950), Isaac B. Singer (cf. Singer \& Burgin 1985), John Maxwell Coetzee (1999), Peter Singer (1990 [1975]) and Charles Patterson (2002), as well as a host of other thinkers and animal rights activists - did not equalise the victims but rather signalled the same type of crime. Marjorie Garber reflects on the aforementioned parallelism as a challenge to humanism, noting that the Holocaust is to many an event beyond analogy, and also addresses the question whether zoo-metaphors (for example, the widely-used scapegoat, or donkey's years, close to the bone, stew in one's own juice, prick up one's ears, easy to digest, baby potatoes) and 
zoo-parables are also unfair: "Viewed in literary terms, this is the challenge to humanism" (cf. Coetzee 2004: 90).

It would seem that those facts - freedom of artistic creativity and the daily Holocaust to which we subject animals - do not make any demand for respecting animal rights in performance arts and art in general, but rather are merely an expression of utopian ludism. It is quite obvious that the ethics of our relationship with animals is marked by dystopia and ethical schizophrenia (see, e.g., Christa Blanke as cited in Patterson 2002: 222-229) and Gary L. Francione (2002)). Unfortunately, we are losing the web of life, ${ }^{17}$ a part of which is also the cockroaches. I conclude by readdressing the motto-question of this article - Is there really nothing nice to be said about cockroaches? - which was also posed by the aforementioned exhibition that documented their path from pests to pets, with both terms being differently anthropocentric, in short - speciesist.

Translated by Andrea Rožić, Ivana Bodul, Maja Boban, Mirta Jurilj

\section{ACKNOWLEDGEMENTS}

This work has been fully supported by the Croatian Science Foundation under the project Narrating Fear (IP-2016-06-2463).

\section{NOTES}

1 Throughout the article I use the he/she pronoun for the animals as I seek to avoid using speciesist language, in the sense of the critique of this language according to feminist and animal rights theoretician Joan Dunayer or, to quote Dunayer herself: 'According to current scientific knowledge, every animal is male, female, or hermaphrodite, so I use he, she, or she/he (alternatively he/she) for any specific nonhuman individual' (Dunayer 2004: XII).

${ }^{2}$ Mark L. Winston remarks that insecticides today still bear military names, such as Ambush or Sidekick (Winston 1997: 47).

3 The Institute for Critical Animal Studies is the first interdisciplinary scholarly centre of higher education dedicated to establishing and expanding the field of critical animal studies.

4 As far as the systematic research of the role of cockroaches in Slavic traditions is concerned, only Aleksandar Gura conducted systematic research of folklore records. For example, the role of cockroaches cannot be found in Tihomir Đorđevićs work titled Priroda u verovanju i predanju našega naroda (Nature in the Faith and Legends of our People), which is the first systematic two-volume book on the role of animals in South-Slavic ethno-traditions. 
5 The monograph was first published as part of the edition Zbornik za narodni život $i$ običaje Južnih Slavena (Collected Papers on the Folk Life and Customs of the Southern Slavs), in 1911-1914, and reprinted in 1992 and 2009.

${ }^{6}$ Blattella germanica or bubašvaba, a species of non-flying cockroach. The word bubašvaba probably comes from the "formal" name of this insect: Blattella germanica German cockroach. It is known that if just one female German cockroach finds her way into a home, she can easily produce an army of hundreds of thousands within a year (Grush 2016).

7 To sum up, Branislava Vičar's article "The Discursive Construction of Insects in TV Advertisements: Multimodal Analysis" reveals that 'the insecticide adverts construct two dominant representations of insects: insects as a nuisance and insects as a threat or danger. The comparison of speciesist rhetoric in the last fifty years has shown that, with the development of corporate capitalism, depictions of insects have become increasingly aggressive and frightening, while the inscribing of negative anthropomorphic constructs has increased; indeed, the aim of constructing this fear of insects and persuading the audience of their potential danger is to increase the sales of insecticides and consequently to increase corporate production' (Vičar 2018). Cf. https:// www.youtube.com/watch?v=iUgUz3sVLGE (Raid Roach Foam: hiding roaches, 1986); https://www.youtube.com/watch?v=YZPuxcLpxyU (Raid MAX Plus Egg Stoppers Roach Bait, 2016), https://www.youtube.com/watch?v=vRl85gdLGy8 (United States - Raid® How To Beat Roaches, 2017), all last accessed on 7 October 2019.

8 In the European Union, insects fall into the category of novel food, which stands for food that had not been consumed to a significant degree by humans in the EU before 15 May 1997 (see Regulation (EC) No. 258/97 on novel foods and novel food ingredients, available at https://eur-lex.europa.eu/legal-content/EN/TXT/PDF/?uri=CELEX:31997R0258\&f rom=EN, last accessed on 7 October 2019) (cf. Rimac Brnčić \& Badanjak Sabolović).

9 Cf. https://www.zastitabilja.eu/madagaskarski-siktajuci-zohar-gromphardorhinaportentosa/, last accessed on 7 October 2019.

10 The French animated comedy series Oggy and the Cockroaches (Oggy et les Cafards), aired from 1998, centres on a blue cat Oggy who would prefer to spend his days contentedly watching television and eating - if not for the three roaches in the household: Joey, Dee Dee, and Marky, all named after members of the punk band Ramones (see https://en.wikipedia.org/wiki/Oggy_and_the_Cockroaches, last accessed on 7 October 2019). I think that this animated comedy series at a certain level produces some more humane attitudes towards cockroaches. Namely, even if the cockroaches are presented as mean and intrusive, they nevertheless prevent Oggy from surrendering himself to the life of a lazy household cat.

${ }^{11} \mathrm{Cf}$. Sandle 2013. Furthermore, there are prognoses that, in the future, humans will use cockroach milk, which is four times more nutritious than cow's milk and could become crucial in feeding our ever-expanding population. It is well-known that the team from the Institute of Stem Cell Biology and Regenerative Medicine in India "has sequenced a protein crystal from the gut of Diploptera punctata (Pacific Beetle Cockroach), the only known cockroach to give birth to live young". On the other hand, one could sarcastically add that cockroach milk will be the superfood of the future because cockroaches will remain in this world even after the human race dies out following the potential - and entirely realistic, according to certain political circles - scenario of nuclear war (cf. Ratner 2016). 
${ }^{12}$ In her video work Gas Chamber, the artist stated that no roaches had been harmed in the making of said work (cf. https://vimeo.com/25535616, last accessed on 7 October 2019).

${ }^{13}$ See https://www.catherinechalmers.com/crawl-space-video, last accessed on 7 October 2019.

${ }^{14}$ See https://www.catherinechalmers.com/american-cockroach-interview, last accessed on 16 October 2019.

${ }^{15}$ See https://vimeo.com/25525065, last accessed on 16 October 2019.

${ }^{16} \mathrm{Cf}$. https://www.catherinechalmers.com/american-cockroach-interview, https://www. youtube.com/watch?v=MgiHXTrqRT8 (Catherine Chalmers, Collaborating with insects, last accessed on 16 October 2019).

${ }^{17} \mathrm{Cf}$. https://unearthed.greenpeace.org/2019/05/06/nature-crisis-biodiversity-dangerousclimate-change-extinction/, last accessed on 7 October 2019.

\section{REFERENCES}

Adorno, Theodor W. \& Frenkel-Brunswik, Else \& Levinson, Daniel J. \& Sanford, R. Nevitt 1950. The Authoritarian Personality. New York: Harper and Row.

Baker, Steve 2000. The Postmodern Animal. London: Reaktion Books.

Baker, Steve 2013. Artist/Animal. Minneapolis \& London: University of Minnesota Press.

Batinić, Ana 2013. U carstvu životinja: animalističko čitanje hrvatskih dječjih časopisa. [In the Animal Kingdom: Reading of Croatian Children's Magazines from Animal Studies Viewpoint.] Zagreb: Hrvatska sveučilišna naklada, Filozofski fakultet.

Best, Steven 2009. The Rise of Critical Animal Studies: Putting Theory into Action and Animal Liberation into Higher Education. Journal for Critical Animal Studies. Vol. 7, No. 1, pp. 9-52. Available at http://www.criticalanimalstudies.org/volumevii-issue-i-2009/, last accessed on 8 October 2019.

Biehler, Dawn Day 2013. Pests in the City: Flies, Bedbugs, Cockroaches, and Rats. Foreword by William Cronon. Washington: University of Washington Press.

Bittel, Jason 2013. PETA against Cyborg Cockroaches. Stuff.co.nz, 6 November. Available at https://www.stuff.co.nz/technology/gadgets/30002970/peta-against-cyborgcockroaches, last accessed on 8 October 2019.

Blatta orientalis $=$ Blatta orientalis - crni žohar. [Blatta orientalis - Black Cockroach.] Adlibitum.hr. Available at http://www.adlibitum.hr/blatta-orientalis-crni-zohar/, last accessed on 4 October 2019.

Boxer, Sarah 2003. Cockroaches as Shadow and Metaphor; An Artist Began Chilling and Decorating Bugs, But Moved On to Depicting Their Executions. The New York Times, 8 May. Available at https://www.nytimes.com/2003/05/08/arts/cockroachesshadow-metaphor-artist-began-chilling-decorating-bugs-but-moved.html, last accessed on 8 October 2019.

Bubašvaba. [Cockroach.] Lexicon: Moraš pazit’ ka'ci na vodi. Available at http://leksikon. thinking-garment.com/bubasvaba-bubasvabo/, last accessed on 8 October 2019. 
Chalmers, Catherine 2004. Excerpts from a Conversation, with Lesley A. Martin. From American Cockroach (Aperture 2004). Available at https://www. catherinechalmers.com/american-cockroach-interview, last accessed on 7 October 2019.

Coetzee, John M. 1999. The Lives of Animals. Princeton: Princeton University Press. Coetzee, John M. 2004. Život životinjâ. [Animal Life.] Zagreb: AGM.

Copeland, Marion 2003. Cockroach. London: Reaktion Books.

Crni žohar. [Black Cockroach.] Id90.hr. Available at http://www.id90.hr/kukci/zohari/ crni-zohar, last accessed on 8 October 2019.

DeMello, Margo 2012. Animals and Society: An Introduction to Human-Animal Studies. New York: Columbia University Press.

Douglas, Mary 1984 [1966]. Purity and Danger: An Analysis of the Concepts of Pollution and Taboo. New York: Routledge \& Kegan Paul.

Dunayer, Joan 2004. Speciesism. Derwood, MD: Ryce Publishing.

Francione, Gary L. 2002. An Interview with Professor Gary L. Francione on the State of the U.S. Animal Rights Movement. Reprinted from Act'ionLine, the Friends of Animals magazine. Available at: https://antispe.de/txt/interviewgaryfrancione. html, last accessed on 8 October 2019.

Grush, Loren 2016. The Verge Review of Animals: The Cockroach, The Perfect Organism. Theverge.com, 17 January. Available at https://www.theverge. com/2016/1/17/10777040/cockroach-animal-review, last accessed on 3 October 2019.

Gura, Aleksandar 2005. Simbolika životinja u slovenskoj narodnoj tradiciji. [Symbolism of Animals in the Slavic Folk Tradition.] Transl. by Ljudmila Joksimović. Beograd: Brimo, Globosino, Logos.

Kišpatić, Mišo 1887. Kukci: Prirodopisne crtice. Knjiga II. [Bugs: Natural History Sketches. Book II.] Zagreb: Matica hrvatska. Available at http://fliphtml5.com/ iiuvs/lvxu, last accessed on 8 October 2019.

Kos, Tina 2016. Genijalan trik kako se riješiti žohara i pauka jednom zauvijek. [An Ingenious Trick to Get Rid of Cockroaches and Siders Once and for All.] 24sta.hr, 16 September. Available at https://www.24sata.hr/lifestyle/genijalan-trik-kako-serijesiti-zohara-i-pauka-jednom-zauvijek-491253, last accessed on 4 October 2019.

Lang, Milan 1992 [1915]. Samobor: Narodni život i običaji. [Samobor: People's Life and Customs.] Reprint. Samobor: “Zagreb”, Poduzeće za grafičku djelatnost.

Leismann, Burkhard \& Padberg, Martina 2010. Intimacy! Baden in der Kunst / Bathing in Art. Ahlen: Kunstmuseum Ahlen; Cologne: Wienand.

Marjanić, Suzana 2017a. The Anthropology of Animals - Paradox and/or Necessity. In: Marjetka Golež Kaučić (ed.) What to Do with Folklore? New Perspectives on Folklore Research. BASIS, Vol. 9, pp. 123-139. Available at https://www.academia. edu/34237850/, last accessed on 8 October 2019.

Marjanić, Suzana 2017b. Zoo-Ethical Implications of Contemporary Performance Arts: Tajči Čekada's She-Boar and Trans-Hare Meet Mary Britton Clouse's HumanChicken Unison. Americana, Vol. 13, No. 2. Available at http://americanaejournal. hu/vol13no2/marjanic, last accessed on 8 October 2019.

Patterson, Charles 2002. Eternal Treblinka: Our Treatment of Animals and the Holocaust. New York: Lantern Books. Available at http://www.elholocausto.net/ pdf2/Charles\%20Patterson\%20-\%20Eternal\%20Treblinka.pdf, last accessed on 15 October 2019. 
Ratner, Paul 2016. Cockroach Milk: The Superfood of the Future is Now. Bigthink.com, 26 July. Available at: https://bigthink.com/paul-ratner/this-gross-creature-maycreate-the-superfood-of-the-future, last accessed on 8 October 2019.

Rimac Brnčić, Suzana \& Badanjak Sabolović, Marija. Jestivi kukci: Nova i/ili tradicionalna hrana. [Edible Insects: New and/or Traditional Food.] Available at https://www. hgk.hr/documents/jestivi-kukci-nova-i-ili-tradicionalna-hrana596f21c2adf51.pdf, last accessed on 7 October 2019.

Sandle, Tim 2013. RoboRoach, the Making of a Radio-Controlled Cockroach. Digital Journal, 12 October. Available at http://www.digitaljournal.com/article/360105, last accessed on 8 October 2019.

Sax, Boria 1990. The Frog King: On Legends, Fables, Fairy Tales and Anecdotes of Animals. New York: Pace University Press. Available at https://archive.org/ details/frogkingonlegend00saxb, last accessed on 8 October 2019.

Sax, Boria 2007. The Cosmic Spider and Her Worldwide Web: Sacred and Symbolic Animals in the Era of Change. In: Randy Malamud (ed.) A Cultural History of Animals in the Modern Age. Oxford \& New York: Berg, pp. 27-48.

Singer, Isaac Bashevis \& Burgin, Richard 1985. Conversations with Isaac Bashevis Singer. New York: Doubleday.

Singer, Peter 1990 [1975]. Animal Liberation. 2nd edition. New York: Avon Books.

Sladetić, Ana 2016. Vizualni ogledi o čistoći: zid kao mjesto, prostor i sjećanje. Dissertation. [Visual Essays on Purity: The Wall as a Place, Space, and Memory.] Diss. (PhD Thesis). Unpublished manuscript. Academy of Fine Arts, University of Zagreb.

The RoboRoach Bundle. Backyardbrains.com. Available at https://backyardbrains.com/ products/roboroach, last accessed on 7 October 2019.

Vičar, Branislava (forthcoming). Diskurzivna konstrukcija kukaca u televizijskim oglasima: multimodalna analiza. [The Discursive Construction of Insects in TV Advertisements: Multimodal Analysis.] In: Marija Geiger Zeman \& Zdenko Zeman \& Suzana Marjanić (eds.) Filmski zoo. [Cinematic Zoo.] Zagreb.

Visković, Nikola 1996. Životinja i čovjek: Prilog kulturnoj zoologiji. [Animal and Man: A Contribution to Cultural Zoology.] Split: Književni krug.

Žohari - svijet koji ostaje. [Cockroaches - A World That Remains.] Exhibition and concept author: dr. sc. Iva Mihoci. Authors of the exhibition and the catalogue: Iva Mihoci, Petar Crnčan, Vlatka Mičetić Stanković and Mirna Klaić. Zagreb: Hrvatski prirodoslovni muzej.

Waibel, Alf 1998. Describing the August 3-9 Nitsch Orgy Mystery Theatre. Sat, 15 Aug. 1998. Nitsch, Hermann. Abstieg in den Grundexzeß. Available at: http://www. xs4all.nl/ jeroenvu/gwv/nitsch.htm, last accessed on 16 October 2019.

Winston, Mark L. 1997. Nature Wars: People vs. Pests. Cambridge, MA \& London, England: Harvard University Press.

Suzana Marjanić, PhD, works at the Institute of Ethnology and Folklore Research in Zagreb, Croatia, as research advisor. Her main fields of research include theories of ritual and myth, animal studies, and performance studies. suzana@ief.hr 